\title{
STRATEGI PENINGKATAN MOTIVASI SISWA DALAM PEMBELAJARAN MATEMATIKA DI KELAS
}

\author{
Vani Rahmayani ${ }^{1}$ dan Rizki Amalia ${ }^{2}$ \\ Program Studi Pendidikan Matematika, Tarbiyah, Universitas Islam Sultan Syarif \\ Kasim Riau, Pekanbaru ${ }^{1}$ \\ Program Studi Pendidikan Guru Pendidikan Anak Usia Dini, Fakultas IImu \\ Pendidikan, Universitas Pahlawan Tuanku Tambusai, Bangkinang ${ }^{2}$
}

Email : vanirahmayani@gmail.com

\begin{abstract}
Abstrak
Pelajaran Matematika merupakan pelajaran yang bersifat abstrak. Bila dalam pelajaran Matematika terjadi permasalahan seperti tidak semangatnya siswa dalam belajar akan berdampak pada berkurangnya keaktifan siswa di kelas. Salah satu permasalahan yang dialami siswa yaitu rendahnya motivasi siswa dalam belajar Matematika. Untuk itu sebagai guru mata pelajaran Matematika perlu adanya ide-ide atau strategi-strategi untuk meningkatkan motivasi siswa dalam belajar Matematika.
\end{abstract}

Kata kunci: Matematika, Motivasi, Strategi

\section{Abstract}

Mathematics is an abstract subject. If there are problems in Mathematics, such as the lack of enthusiasm for students in learning, it will have an impact on reducing student activity in class. One of the problems experienced by students is the low motivation of students in learning mathematics. For this reason, as a Mathematics teacher, ideas or strategies are needed to increase student motivation in learning Mathematics.

Keywords: Mathematics, Motivation, Strategy

\section{PENDAHULUAN}

Belajar merupakan kegiatan sehari-hari bagi siswa sekolah; baik itu SD, SMP, SMA, maupun Perguruan Tinggi. Kegiatan belajar tersebut ada yang dilakukan di sekolah, di rumah, dan ditempat lain seperti museum, perpustakaan, kebun binatang, dan lainnya. Kegiatan belajar yang termasuk rancangan guru, yaitu bila siswa belajar di tempat-tempat tersebut untuk mengerjakan tugas-tugas yang diberikan oleh guru. Di samping itu ada juga kegiatan belajar yang tidak termasuk rancangan guru. Artinya, siswa belajar karena keinginannya sendiri; baik itu di sekolah, di rumah, maupun di tempat-tempat lainnya. Pengetahuan tentang "belajar, karena ditugasi" dan "belajar, karena motivasi diri" penting bagi semua guru maupun bagi calon guru agar dapat memantau proses belajar siswanya, sehingga tujuan guru untuk membuat siswanya memahami pelajaran 
yang diberikan dapat terlaksana dengan baik.

Semua anak mempunyai motivasi untuk belajar dari rasa ingin tahu secara alami sejak mereka kecil. Tetapi sejalan dengan semakin bertumbuhnya seseorang, ketertarikan untuk belajar dan semangat untuk belajar seseorang semakin berkurang, dan tidak jarang mereka menjadikan belajar sebagai sebuah beban. Menurunnya motivasi dan munculnya kebosanan di kelas dapat mengarah pada masalah kedisiplinan. Karena mereka tidak memiliki motivasi dalam belajar menyebabkan mereka menjadi malas, bosan, nakal, dan tak jarang mereka akan mengganggu proses belajar-mengajar seperti mengganggu temannya yang sedang belajar atau malah mengganggu gurunya yang sedang mengajar.

Dalam pembelajaran Matematika khususnya, banyak juga ditemukan siswa yang tidak memiliki motivasi dalam belajar Matematika. Kebanyakan kasus dikarenakan mereka tidak memahami ataupun tidak mengerti dengan pelajaran Matematika ini. Tetapi ada juga anak yang memiliki motivasi belajar Matematika yang tinggi, seperti ada anak yang berkesulitan belajar dalam membaca maupun menghafal, tetapi mereka memiliki keterampilan yang besar di pelajaran Matematika. Dengan kata lain, karakteristik dan motivasi setiap anak dalam belajar Matematika tidaklah sama. Oleh karena itu, guru haruslah memperhatikan karakteristik kesulitan belajar serta motivasi belajar Matematika masing-masing anak sehingga guru dapat memberikan pengajaran yang baik serta dapat diterima oleh siswanya.

Kesulitan belajar Matematika yang dirasakan oleh siswa kebanyakan disebabkan oleh Matematika yang memiliki sifat abstrak, dan guru yang terlalu monoton dalam mengajarkan Matematika; sehingga karena hal-hal tersebut menyebabkan tidak sedikit siswa yang kurang memahami dan kurang termotivasi dalam pembelajaran Matematika di kelas. Karena pembelajaran Matematika merupakan pembelajaran yang memerlukan penalaran yang tinggi, sehingga siswa harus dapat memahami konsep Matematika secara jelas agar dapat memahami Matematika dengan baik.

Timbulnya kesulitan belajar dan kurangnya motivasi siswa dalam belajar Matematika juga bisa terjadi karena model pembelajaran yang diterapkan oleh guru lebih bersifat monoton dan tidak memberikan kesempatan kepada siswanya untuk lebih aktif di dalam kelas dengan ide-idenya sendiri. Dan juga banyak siswa yang memiliki rasa takut "SALAH" dalam menjawab soal Matematika. Karena itu semua, potensi yang dimiliki siswa sulit dikembangkan dan menyebabkan siswa kurang termotivasi dalam proses pembelajaran Matematika.

Namun, meskipun seorang guru telah melakukan segala cara dalam memotivasi siswa belajar Matematika ada kemungkinan beberapa siswa di kelas yang tetap tidak menyukai Matematika dan mengganggu proses pembelajaran yang berlangsung, sehingga sebagai guru yang professional perlu mengatur siswa tanpa bersikap tidak ramah dan agresif.

Oleh karena itu, seorang guru harus dapat memahami karakteristik kesulitan belajar Matematika yang dialami oleh siswanya. Dengan begitu seorang guru dapat mengambil tindakan ataupun strategi pembelajaran yang tepat untuk 
diterapkan di kelasnya, sehingga siswanya bisa dengan mudah memahami konsep Matematika dan menjadikan Matematika tidak lagi menjadi pelajaran yang membosankan dan menakutkan, serta menjadikan pembelajaran Matematika sebagai suatu pelajaran yang mengasikkan untuk seluruh siswa.

\section{PEMBAHASAN}

Matematika tidak dapat disamakan dengan berhitung atau aritmatika. Matematika adalah pengetahuan dasar yang diperlukan oleh siswa untuk menunjang keberhasilan belajarnya dalam menempuh pendidikan yang lebih tinggi lagi. Dalam Undang-Undang RI Tahun 2003 tentang Sisdiknas Pasal 37 menegaskan bahwa mata pelajaran Matematika merupakan salah satu mata pelajaran wajib bagi siswa pada jenjang pendidikan dasar dan menengah.

Pengertian Matematika yang tepat tidak dapat ditentukan secara pasti. Hal ini karena cabang-cabang Matematika semakin bertambah dan semakin berbaur satu dengan lainnya. Beth \& Piaget (1956) mengatakan bahwa yang dimaksud dengan Matematika adalah pengetahuan yang berkaitan dengan berbagai struktur abstrak dan hubungan antar struktur tersebut sehingga terorganisasi dengan baik. Di pihak lain, Reys dkk., (2002) mengatakan bahwa Matematika adalah studi tentang pola dan hubungan, cara berpikir dengan strategi organisasi, analisis dan sintesis, seni, bahasa, dan alat untuk memecahkan masalah-masalah abstrak dan praktis.

Beberapa kesulitan belajar Matematika yang menyebabkan siswa tidak memiliki motivasi yang besar terhadap pelajaran ini, yaitu:

1) Kesulitan dalam memahami konsep dasar dalam Matematika.

2) Kesulitan dalam menulis dan menggambar, kesulitan memahami berbagai objek terkait himpunan objek.

3) Kesulitan kemampuan menghitung dan kemampuan membandingkan.

4) Kesulitan mengenal dan memahami simbol.

5) Mereka tidak mengerti apa manfaat praktis dari pelajaran Matematika yang mereka pelajari.

6) Mereka tidak menikmati suasana belajar di dalam kelas.

Matematika sangat perlu untuk diajarkan di setiap jenjang pendidikan. Karena pelajaran Matematika bersifat abstrak, maka dalam mempelajari dan mengajarinya perlu adanya kiat-kiat khusus. Seorang guru yang mengajarinya tidak cukup hanya mampu menguasai materinya saja, tetapi juga harus menguasai kelas dan siswa agar para siswa dapat meningkatkan motivasi belajar mereka.

Berdasarkan analisis tentang motivasi, maka secara umum motivasi dapat dibagi menjadi dua jenis, yaitu:

1) Motivasi Intrinsik.

Motivasi Intrinsik sering disebut Motivasi Murni. Motivasi Intrinsik adalah motivasi yang timbul dari dalam diri siswa itu sendiri dan berguna dalam situasi belajar yang fungsional. Ciri-ciri seseorang yang memiliki motivasi ini yaitu tekun menghadapi tugas, ulet menghadapi kesulitan, menunjukkan minat terhadap bermacam- 
macam masalah, lebih senang bekerja mandiri, dan senang mencari dan memecahkan masalah soal-soal. Dalam hal ini pujian atau hadiah atau sejenisnya tidak diperlukan oleh siswa tersebut karena tidak akan menyebabkan siswa bekerja atau belajar untuk mendapatkan pujian atau hadiah itu.

2) Motivasi Ekstrinsik.

Motivasi ekstrinsik adalah motivasi yang disebabkan oleh faktor-faktor dari luar situasi belajar; seperti angka atau nilai, ijazah, tingkatan hadiah, mendali, dan hukuman. Motivasi ekstrinsik ini tetap diperlukan di sekolah, sebab pengajaran di sekolah tidak semuanya menarik minat dan motivasi siswa.

Motivasi dalam belajar sangat penting bagi siswa maupun bagi guru itu sendiri. Bagi siswa, motivasi perlu disadari oleh pelakunya sendiri sehingga suatu pekerjaan atau tugas belajar akan selesai dengan baik. Bagi guru, motivasi dalam mengajar juga sangat diperlukan guna dapat membangkitkan semangat dan motivasi belajar siswanya. Bagaimana pun guru menyampaikan pembelajaran dengan baik dan sempurna, namun jika siswanya tidak memiliki motivasi yang tinggi, maka siswa tidak akan belajar dengan baik dan tidak akan tercapainya prestasi belajar. Motivasi dalam belajar juga dapat dipengaruhi oleh kecemasan siswa dalam belajar, sehingga siswa menjadi tertekan.

Menurut Nurlaela (2010: 74), untuk menjadi guru yang penuh dengan motivasi, ada beberapa yang harus dilakukan seorang guru agar apa yang diajarkannya dapat dipahami oleh siswa, yaitu:

1. Sederhanakan penjelasan dalam mengajar dengan bahasa yang mudah dipahami siswa.

2. Baca visi dan misi dari suatu materi pelajaran dan juga tujuan pembelajarannya, agar mudah untuk menyampaikan pembelajaran kepada siswa.

3. Ajak siswa untuk belajar di luar ruangan jika keadaan dalam kelas sudah tidak lagi kondusif dan membosankan.

4. Bantu siswa untuk menentukan mata pelajaran apa yang paling mereka sukai.

\section{Strategi Memotifasi siswa}

Menurut Oemar, (2015) Mengatakan; Agar siswa memiliki motivasi yang besar untuk belajar Matematika, ada beberapa strategi yang dapat dilakukan oleh guru pelajaran Matematika untuk memotivasi siswanya. Guru dapat meningkatkan motivasi dengan membangkitkan ketertarikan siswa, mempertahankan keingintahuan, menggunakan berbagai cara presentasi, dan memberi kesempatan siswa menentukan sasaran mereka sendiri.

Apabila siswa termotivasi, maka kemungkinan besar tidak ada lagi siswa yang menjadi pengganggu di dalam proses belajar-mengajar. Berikut ini beberapa ide yang dapat digunakan oleh guru untuk memotivasi siswa di dalam kelas, seperti:

1) Gunakan Metode dan Kegiatan Yang Beragam. Dalam pembelajaran Matematika juga perlu diadakannya kegiatan yang menyenangkan 
untuk siswa, agar siswa lebih tertarik dan termotivasi untuk belajar Matematika, baik itu kegiatan di dalam kelas maupun kegiatan di luar kelas.

2) Jadikan Siswa Peserta Aktif. Meskipun dalam pembelajaran Matematika yang notabennya adalah nilai pasti, siswa juga harus aktif dalam menyampaikan ide-idenya untuk penyelesaian suatu masalah sehingga menumbuhkan motivasi dalam belajar.

3) Ciptakan Suasana Kelas Yang Kondusif. Sebagai seorang guru, sebaiknya harus dapat menghargai siswa dengan tidak hanya memandang kemampuan akademis mereka, sehingga mereka akan terdorong untuk terus mengikuti proses belajar.

4) Libatkan Diri Untuk Membantu Siswa Dalam Mencapai Hasil. Dalam pelajaran Matematika khususnya, seorang guru juga harus membimbing siswanya untuk bisa menyelesaikan soal yang di berikannya. Jangan hanya terpaku pada hasil ujian atau tugas, tetapi pada proses yang dijalani siswa.

5) Hindari Kompetisi AntarPribadi. Sebagai guru, janganlah sampai menciptakan kompetisi antar siswanya. Karena kompetisi bisa menimbulkan kekhawatiran yang bisa berdampak buruk bagi proses belajar dan akan membuat sebagian siswa bertindak curang.

6) Antusias Dalam Mengajar. Sebagai seorang guru khususnya guru Matematika, penting untuk antusias dalam mengajar guna menumbuhkan motivasi dan semangat belajar dalam diri siswanya. Jangan menjadi guru yang terlihat bosan dan kurang semangat, karena juga akan berdampak buruk pada motivasi dan semangat siswa.

7) Pemberian Penghargaan Untuk Memotivasi. Berilah penghargaan seperti nilai, hadiah, dan sebagainya ketika siswa dapat menjawab soal yang diberikan. Tetapi metode ini harus digunakan secara hatihati karena berpotensi menciptakan kompetisi.

8) Ciptakan Aktivitas Yang Melibatkan Seluruh Siswa Dalam Kelas. Buatlah aktivitas yang melibatkan siswa dengan teman-temannya dalam satu kelas. Seperti dibuatnya kelompok yang terdiri atas 4-5 orang, dan berikan soal Matematika yang berbeda kepada tiap kelompok. Sehingga mereka akan terlibat satu sama lain untuk dapat menyelesaikan soal Matematika tersebut.

9) Hindari Penggunaan Ancaman. Dalam proses belajar-mengajar jangan mengancam siswa dengan kekerasan, hukuman ataupun nilai rendah. Bagi sebagian siswa ancaman untuk memberi nilai rendah mungkin efektif, tetapi hal tersebut bisa memicu mereka mengambil jalan pintas untuk "menyontek".

Jangan Menjadi Guru Yang Ditakuti Oleh Siswa. Sebagai guru Matematika yang selalu dikatakan sebagai guru "killer", hendaknya dapat mengubah presepsi buruk itu dengan tidak menjadi guru yang pemarah. Sebaiknya sebagai guru Matematika, berusahalah untuk selalu sabar dan membimbing siswa dalam belajar-mengajar di kelas.

\section{SIMPULAN}

Dalam pelajaran Matematika dapat dikatakan pelajaran yang memiliki kesulitan tinggi, karena pelajaran Matematika ini memiliki sifat abstrak yang tidak dapat dipahami oleh semua siswa. Karena hal itu membuat motivasi siswa dalam belajar Matematika semakin berkurang. Guru Matematika sebaiknya melakukan strategi bagi anak yang memiliki motivasi rendah dalam belajar Matematika. 
Strategi yang dapat dilakukan oleh guru yaitu gunakan metode dan kegiatan yang beragam, jadikan siswa peserta aktif, ciptakan suasana kelas yang kondusif, libatkan diri untuk membantu siswa dalam mencapai hasil, hindari kompetisi antarpribadi, antusias dalam mengajar, pemberian penghargaan untuk memotivasi, ciptakan aktivitas yang melibatkan seluruh siswa dalam kelas, hindari penggunaan ancaman, dan jangan menjadi guru yang ditakuti oleh siswa.

\section{DAFTAR PUSTAKA}

Abidin, Zaenal. Upaya Meningkatkan Motivasi dan Pemahaman Siswa Pada Materi Geometrid an Pengukuran Melalui Kegiatan "Remase" di SMP 33 Semarang. Jurnal: Kreano. Vol. 2 No. 2, Desember 2011, Hal. 133-141.

Dimyati dan Mudjiono. 2006. Belajar dan Pembelajaran. Jakarta: PT Rineka Cipta.

Hamalik, Oemar. 2015. Proses Belajar Mengajar. Jakarta: PT Bumi Aksara.

Ismail, Husain. Peningkatan Motivasi Belajar Matematika Melalui Pembelajaran Berbasis Masalah Pada Siswa Kelas V SD Inpres Palupi. Jurnal: Kreatif Tadulako Online. Vol. 4 No. 4, Hal. 343-350.

Isnawati, Nurlaela. 2010. Guru Positif - Motivatif. Yogyakarta: Penerbit Laksana.

Khasanah, Nur. Hubungan Motivasi Belajar Dan Persepsi Siswa Terhadap Pelajaran Matematika Dengan Hasil Belajar Matematika Siswa Kelas VIII SMP N 1 Jetis. Jurnal: Pendidikan Matematika. Vol. 4 No. 3, November 2016, Hal. 413-418.

Lestari, Zuly. Hubungan Antara Persepsi Siswa Terhadap Kemampuan Mengajar Guru, Keaktivan Belajar dan Motivasi Belajar Dengan Prestasi Belajar Matematika Siswa Kelas VIII SMP N 2 Salam. Jurnal: Pendidikan Matematika. Vol. 4 No. 1, Maret 2016, Hal. 57-64.

Majid, Abdul. 2014. Strategi Pembelajaran. Bandung: PT Remaja Rosdakarya.

Runtukahu, Tombokan dan Selpius Kandou. 2014. Pembelajaran Matematika Dasar Bagi Anak Berkesulitan Belajar. Yogyakarta: Ar-Ruzz Media.

Slavin, Robert E. 2011. Psikologi Pendidikan: Teori dan Praktik. Jakarta Barat: PT Indeks.

Suardana, Anak Agung Putu Chintya Putri. Hubungan Antara Motivasi Belajar dan Kecemasan Pada Siswa Kelas VI Sekolah Dasar di Denpasar Menjelang Ujian Nasional. Jurnal: Psikologi Udayana. Vol. 1 No. 1, 2013, Hal. 203-212.

Susanti, Anis. Pengaruh Motivasi Belajar Siswa Terhadap Prestasi Belajar Matematika Siswa. Jurnal: Pendidikan Matematika. Vol. 3 No. 2, September 2015, Hal. 151-158.

Suwoto. Peningkatan Motivasi Belajar Melalui Pembelajaran Matematika Realistik Pada Siswa Kelas IX SMP Negeri 1 Sumbergempol Kabupaten Tulungagung. Jurnal: Dinamika. Vol. 15 No. 1, Juli 2015, Hal. 105-116. 
Taneo, Astriyani R. Analisis Motivasi Belajar Mahasiswa Pada Pembelajaran Kalkulus Integral Berbasis Maple. Jurnal: Publikasi Pendidikan. Vol. 9 No. 1, Februari 2019, Hal. 12-18.

Yanti, Supri. Hubungan Antara Kecemasan Dalam Belajar Dengan Motivasi Belajar Siswa. Jurnal: IImiah Konseling. Vol. 2 No. 1, Januari 2013, Hal 283-288. 